\title{
The effect of eight-week core stability training program on the dynamic balance in young elite footballers
}

\author{
J Abdi ${ }^{*}, \mathrm{H}$ Sadeghi ${ }^{2}$ \\ From 9th International Conference on Conservative Management of Spinal Deformities - SOSORT 2012 \\ Annual Meeting \\ Milan, Italy. 10-12 May 2012
}

\section{Background}

Core stability is the central motor control and muscular capacity of the lumbar-pelvic-thigh to maintain stability of this region against various postural and external forces [1]. Studies, have been shown different roles of core stability to improve performance; Lewarchik (2003) tend to stabilize the core in footballers not observed significant using the stability exercise program and plyometric [2]. Kahle(2009) have been shown improved postural control after six weeks core stability training program in healthy and young adults [3]. Accordingly, there are different results of research, and important training on postural stability in the football skills.

\section{Aim}

The purpose of this study was the effect of eight-week core stability training program on the dynamic balance in young elite footballers.

\section{Methods}

Statistical 15 football players, 19 to 24 years in FC Tehran Damash with mean age $21.10 \pm 1.25$ years, height $179.53 \pm 6.83 \mathrm{~cm}$, weight $71.80 \pm 7.42 \mathrm{~kg}$, body mass index $22.23 \pm 1.27 \mathrm{~kg} / \mathrm{m} 2$ and a maximum vertical jump was $51.66 \pm 5.58 \mathrm{~cm}$. performance eight-week core stability training program with three sessions a week for 30 minutes was run. Control of dynamic balance on the force plate, at the dominant and non dominant leg, through jump-landing with a $50 \%$ vertical jump

${ }^{1}$ Islamic Azad University, Central Tehran Branch, Teheran, Iran

Full list of author information is available at the end of the article maximum, in pre and post test was evaluated by dynamic postural stability index. The data analysis by paired t-test, one-way analysis of variance (ANOVA) and Tukey post hoc test at significance level $0 / 05$ was used.

\section{Results}

Results findings a high level significantly in progress dynamic balance in the medial-lateral, anterior-posterior and vertical directions and dynamic postural stability of the whole proved.

\section{Discussion}

The results of the study are dissimilar with the Lewarchik study. Possible causes of dissimilation are age of subjects and measuring. And similar with the Kahle study, possible reasons can be exercise protocol. Core muscle contraction of the member, the reaction between postural disorders of the central nervous system that prevents postural and core stability exercise program, can result in improved prediction of activity, and thereby reducing the disruption displacement and fluctuates of the center of gravity.

\footnotetext{
Author details

${ }^{1}$ Islamic Azad University, Central Tehran Branch, Teheran, Iran. ${ }^{2}$ Orthopedic \& Rehabilitation, Tehran Tarbiat Moallem University, Teheran, Iran.

Published: 3 June 2013

\section{References}

1. Carpes FP, Reinehr FB, Mota CB: Effects of a program for trunk strength and stability on pain, low back and pelvis kinematics, and body balance: a pilot study. J Bodyw Mov Ther 2008, 12(1):22-30.

2. Lewarchik T, B M, Bradley D, Hughes C, Smith T: The effects of a seven week core stabilization program on athletic performance in collegiate football players. J Ath/ Train 2003, 38S:S-81.
} 
3. Kahle N: The Effects of Core Stability Training on Balance Testing in Young Healthy Adults. The University of Toledo; 2009.

doi:10.1186/1748-7161-8-S1-P20

Cite this article as: Abdi and Sadeghi: The effect of eight-week core

stability training program on the dynamic balance in young elite

footballers. Scoliosis 2013 8(Suppl 1):P20.

Submit your next manuscript to BioMed Central and take full advantage of:

- Convenient online submission

- Thorough peer review

- No space constraints or color figure charges

- Immediate publication on acceptance

- Inclusion in PubMed, CAS, Scopus and Google Scholar

- Research which is freely available for redistribution

Submit your manuscript at 